\title{
PENINGKATAN PEMAHAMAN JAKSA TERHADAP KEBIJAKAN HUKUM PIDANA DALAM MENANGGULANGI TINDAK PIDANA DI BIDANG PERTAMBANGAN
}

\author{
Ade Adhari, Neysa Tania dan Hans Poliman \\ Fakultas Hukum, Universitas Tarumanagara, Jakarta \\ Surel: adea@fh.untar.ac.id
}

\begin{abstract}
In the criminal justice system in Indonesia, there are Public Prosecutors who run applications for various types of criminal acts, including crimes in the mineral and coal mining sector. This community service activity is useful for providing understanding to prosecutors about criminal law policies in the mineral and coal mining sector. This activity was carried out boldly by using a virtual zoom meeting. The implementation of this activity involves prosecutors in various prosecutors' offices in Indonesia. Lectures were chosen as a method of implementing community service. The results of this activity indicate that prosecutors gain an increased understanding of how the policy of tackling violations of criminal provisions in the Minerba Law by using the means of criminal sanctions.
\end{abstract}

Keywords: Mining, Penal Policy, Prosecutor

\section{ABSTRAK}

Dalam sistem peradilan pidana di Indonesia, terdapat Jaksa Penuntut Umum yang menjalankan kewenangan penuntutan terhadap berbagai jenis tindak pidana termasuk di dalamnya tindak pidana di bidang pertambangan mineral dan batubara. Kegiatan pengabdian kepada masyarakat ini berguna untuk memberikan pemahaman kepada para jaksa tentang kebijakan hukum pidana di bidang pertambangan mineral dan batubara. Kegiatan ini dilakukan secara daring dengan menggunakan virtual zoom meeting. Pelaksanaan kegiatan ini melibatkan jaksa di berbagai kejaksanaan di Indonesia. Ceramah dipilih sebagai metode pelaksanaan pengabdian kepada masyarakat. Hasil kegiatan ini menunjukan bahwa para jaksa mendapatkan peningkatan pemahaman terkait dengan bagaimana kebijakan penganggulangan pelanggaran terhadap ketentuan pidana dalam UU Minerba dengan menggunakan sarana sanksi pidana.

Kata Kunci: Pertambangan, Kebijakan Hukum Pidana, Jaksa

\section{PENDAHULUAN}

Indonesia merupakan salah satu negara di dunia yang mempunyai sumber daya alam yang melimpah, baik berupa sumber daya yang dapat diperbaharui (renewable) dan tidak dapat diperbaharui (non renewable). Dalam konteks sumber daya alam yang tidak dapat diperbaharui, Indonesia merupakan Negara yang kaya akan bahan tambang kaliber dan diakui oleh dunia (Simon, 2009). Menurut data Kementerian Koordinator Perekonomian, Indonesia dikenal sebagai salah satu negara pengekspor gas alam cair (liquified natural gas - LNG) terbesar di dunia selain Qatar dan Malaysia. Menurut Badan Pusat Statistik, pada tahun 2019, produksi barang tambang mineral Indonesia mengalami peningkatan yang signifikan, yaitu sebesar 616.154.054 batu bara, 16.592.187 bauksit, dan 60.948.143 bijih nikel (Badan Pusat Statistik, 2020). Indonesia juga tercatat sebagai penyimpan cadangan bauksit terbesar nomor tujuh di dunia, sekaligus menjadi produsen bauksit nomor empat di dunia dan produsen nikel terbesar ke4 dari 5 besar negara produsen nikel dunia yang bersama-sama menyumbang lebih dari 60 persen produksi nikel dunia. Indonesia sendiri memiliki 8 persen cadangan nikel dunia. Produksi nikel Indonesia mencapai 190 ribu ton per tahun (Jihan Rona Anisah, et.al, 2020). Adapun tambang memberikan kontribusi sebesar 4,70\% untuk PDB Indonesia saat ini. Itulah sebagian ilustrasi yang membuktikan bahwa Indonesia termasuk salah satu negara yang kaya sumber daya alam di dunia.

Sesuai dengan grundnorm negara Indonesia yaitu Undang-Undang Dasar Negara Republik Indonesia Tahun 1945 (UUD NRI 1945), dinyatakan dalam Pasal 33 ayat (2) dan ayat (3) bahwa 
cabang-cabang produksi yang penting bagi negara dan yang menguasai hajat hidup orang banyak dikuasai oleh negara. Pasal 33 ayat (3) juga menegaskan bahwa "Bumi dan air dan kekayaan alam yang terkandung di dalamnya dikuasai oleh negara dan dipergunakan untuk sebesarbesarnya kemakmuran rakyat". Konsep penguasaan negara atas sumber daya mineral dan batubara di Indonesia didasarkan atas ketentuan dalam Pasal 33 ayat (3) tersebut lah yang menjadi doktrin penguasaan negara dan sekaligus menjadi landasan filosofi dan yuridis pengelolaan sumber daya alam di Indonesia (Ahmad Redi, 2014). Terkait dengan makna "dikuasai oleh negara", Mahkamah Konstitusi di dalam Putusan Mahkamah Konstitusi Perkara Nomor 002/PUU-I/2003 menyatakan bahwa pengertian "dikuasai negara" haruslah diartikan mencakup makna penguasaan oleh negara dalam arti luas yang bersumber dan diturunkan dari konsep kedaulatan rakyat Indonesia atas segala sumber kekayaan "bumi, air dan kekayaan alam yang terkandung di dalamnya", termasuk pula di dalamnya pengertian publik oleh kolektivitas rakyat atas sumber-sumber kekayaan dimaksud. Rakyat secara kolektif itu dikonstruksikan oleh UUD NRI 1945 memberikan mandat kepada negara untuk mengadakan kebijakan (beleid) dan tindakan pengurusan (bestuursdaad), pengaturan (regelendaad), pengelolaan (behersdaad), dan pengawasan (toezichthoudensdaad) untuk tujuan sebesar-besarnya kemakmuran rakyat. Begitupun dengan pendapat Moh. Mahfud MD yang menyatakan bahwa hak menguasai negara seharusnya justru memberi jalan bagi tindakan responsif karena dari hak tersebut pemerintah dapat melakukan tindakan-tindakan yang berpihak bagi kepentingan masyarakat (Moh. Mahfud MD, 1998). Dengan demikian, pengelolaannya perlu dilakukan secara optimal, efisien, transparan, berkelanjutan, berwawasan lingkungan serta berkeadilan agar memperoleh manfaat sebesar-besarnya bagi kemakmuran rakyat.

Negara melalui Pemerintah Pusat bertanggung jawab atas penggunaan Mineral dan Batubara yang ada di wilayah Hukum Negara Kesatuan Republik Indonesia melalui pengelolaan dan pemanfaatan Mineral dan Batubara yang diatur dalam perundang-undangan maupun peraturan yang bersangkutan. Pada Orde Lama, dasar hukum pertambangan menggunakan Pasal 33 ayat (3) UUD NRI 1945 dan Pasal 38 ayat (1) UUDS 1950, Surat DPR RI No.Agd.1446/RM/DPR RI/1951, Undang-Undang Nomor 78 Tahun 1958 tentang Penanaman Modal Asing (mengatur hubungan antar negara dengan swasta, semangat nasionalis dijunjung tinggi oleh Negara), Undang-Undang Nomor 10 Tahun 1959 tentang Pembatalan Hak-Hak Pertambangan, UndangUndang Nomor 37 Prp. Tahun 1960 tentang Pertambangan. Pada Orde baru, dasar hukum yang digunakan untuk kegiatan usaha pertambangan yaitu Pasal 33 ayat (3) UUD NRI 1945, TAP MPRS Nomor XXIII-MPRS/1996, Undang-Undang Nomor 1 Tahun 1967 tentang Penanaman Modal Asing dan Undang-Undang Nomor 11 Tahun 1967 tentang Ketentuan-Ketentuan Pokok Pertambangan. Akhirnya pada masa order baru UU PMA dan Pokok-Pokok Pertambangan mengalami perubahan dengan menyesuaikan kepentingan umum. Saat masa reformasi, ketentuan terkait pertambangan diatur dalam Pasal 33 ayat (3) UUD 1945, Putusan MK Nomor 01-021022/PUU-I/2003 dan Putusan MK lainnya, Undang-Undang Nomor 32 Tahun 2004 tentang Pemerintah Daerah dan Undang-Undang Nomor 4 Tahun 2009 Tentang Pertambangan Mineral dan Batubara (UU Minerba 2009). Dalam UU Minerba 2009, terdapat penyesuaian-penyesuaian pokok yang menjadi kekuatan bagi pengaturan model bisnis pertambangan batubara, namun hal tersebut dinilai belum dapat menjawab permasalahan serta kondisi aktual dalam pelaksanaan pengusahaan pertambangan dan sektor nonpertambangan. Padahal UU Minerba 2009 mulai membuka tentang aspek yuridis tentang pengelolaan pertambangan dari aspek lingkungannya selain juga disinggung tentang kemandirian pertambangan Indonesia. Dari aspek lingkungan Undang-Undang tersebut mulai mengakomodir beberapa permasalahan lingkungan walaupun secara prinsip lingkungan masih banyak terlewati. Berdasarkan hal tersebut, pemerintah menilai perlu dilakukan penyempurnaan terhadap UU Minerba 2009 untuk memberikan kepastian hukum dalam kegiatan pengelolaan dan pengusahaan pertambangan mineral dan batubara bagi 
pelaku usaha di bidang mineral dan batubara (Penjelasan UU No. 3 Tahun 2020). Oleh karena itu, pada tahun 2020, Presiden Joko Widodo mengesahkan Undang-Undang Nomor 3 Tahun 2020 pada tanggal 10 Juni 2020 sebagai penyempurnaan terhadap Undang-Undang Nomor 4 Tahun 2009 tentang Petambangan Mineral dan Batubara yang mengatur materi muatan baru dan penghapusan beberapa pasal yang dinilai belum dapat menjawab permasalahan serta kondisi aktual dalam pelaksanaan pengusahaan Pertambangan Mineral dan Batubara. Saat ini, UU Minerba 2020 dianggap sebagai landasan normatif yang mengatur permasalahan pertambangan Mineral dan Batubara.

Dalam UU Minerba terdapat pengaturan tentang Ketentuan Pidana yang mengatur tentang Tindak Pidana di Bidang Pertambangan. Hal ini tentu menjadi kewenangan dari dari Jaksa sebagai penuntut umum terhadap mereka yang diduga melakukan tindak pidana di bidang pertambangan. Oleh sebab itu, kegiatan PKM ini penting untuk memberikan pemahaman kepada para jaksa tentang tindak pidana di bidang pertambangan, pertanggungjawaban pidana, dan sanksi pidana yang tersedia sebagai bagian dari kebijakan hukum pidana dalam menanggulangi tindak pidana di bidang pertambangan. Berdasarkan informasi yang disampaikan oleh Balai Diklat Kejaksaan Republik Indonesia, kali ini didapatkan pemahaman bahwa: masih kurangnya pengetahuan mengenai hukum pertambangan di ruang lingkup Kejaksaan Republik Indonesia; Masalah yuridis UU Minerba menyebabkan kekeliruan dalam memahami kebijakan hukum pidana yang terdapat dalam UU Minerba; dan lain sebagainya.

\section{METODE PELAKSANAAN PKM}

Pelaksanaan pengabdian kepada masyarakat di Balai Diklat Kejaksaan Republik Indonesia diselenggarakan melalui berbagai tahapan sebagai berikut: Tahapan Penggalian Informasi Permasalahan, penggalian permasalahan kebijakan hukum pidana di bidang pertambangan dilakukan melalui membaca data-data primer yaitu Undang-Undang, data sekunder yaitu buku, jurnal dan prosiding. Tahapan Penyusunan Proposal, penyusunan proposal dilakukan untuk memberikan gambaran kepada mitra mengenai kegiatan pengabdian kepada masyarakat yang akan dilakukan oleh pelaksana. Tahapan Pengurusan Izin Pelaksanaan PKM, pengurusan perizinan dilakukan sesuai dengan prosedur atau peraturan pihak mitra yaitu Balai Diklat Kejaksaan Republik Indonesia dengan tetap mematuhi peraturan kesehatan yang dikeluarkan oleh Pemerintah. Tahapan Pelaksanaan PKM, pelaksanaan perizinan dilakukan secara daring melalui salah satu platform seperti zoom dengan topik "Kebijakan Hukum Pidana Dalam Menanggulangi Tindak Pidana di Bidang Pertambangan." Tahapan Penyusunan Luaran PKM sebagai luaran PKM akan dibuat suatu artikel mengenai topik yang bersangkutan yang akan dipresentasikan dalam seminar nasional. Tahapan Laporan Kemajuan PKM, penyusunan laporan kemajuan PKM berisi mengenai progres pelaksanaan PKM sebagai informasi kepada pihak Universitas Tarumanagara.Tahapan Penyusunan Laporan Akhir PKM, penyusunan laporan akhir berisi keseluruhan pelaksanaan kegiatan PKM serta hasil PKM serta pertanggungjawaban pelaksanaan oleh Peneliti kepada Pihak Universitas Tarumanagara.

Dalam kegiatan pelaksanaan pengabdian kepada masyarakat di Balai Diklat Kejaksaan Republik Indonesia, partisipasi mitra dalam berbagai bentuk sebagai berikut: Menyampaikan informasi tentang adanya pelaksanaan pengabdian kepada masyarakat di Balai Diklat Kejaksaan Republik Indonesia; Mengadakan koordinasi dengan ketua pelaksana Balai Diklat Kejaksaan Republik Indonesia untuk mengikuti kegiatan pengabdian kepada masyarakat; dan Menyusun absensi yang dibutuhkan pada saat pelaksanaan pengabdian kepada masyarakat di Balai Diklat Kejaksaan Republik Indonesia. 


\section{HASIL DAN PEMBAHASAN}

Pengabdian kepada masyarakat ini secara sederhana memberikan pemahaman seputar kebijakan hukum pidana dalam menanggulangi tindak pidana di bidang pertambangan mineral dan batubara yang tertuang dalam bab ketentuan pidana. Menurut Barda Nawawi Arief, dalam melakukan upaya penanggulangan kejahatan dapat dilakukan dengan 2 metode yaitu jalur "penal" (hukum pidana) dan lewat jalur "non-penal" (bukan di luar hukum pidana) (Barda Nawawi Arief, 2011). Merujuk pada pendapat tersebut, ketentuan pidana merupakan bagian dari kebijakan penal dalam menanggulangi tindak pidana di bidang pertambangan. Kebijakan hukum pidana dapat diimplementasikan melalui beberapa tahapan operasional/fungsionalisasi hukum pidana yang terdiri dari: Kebijakan formulasi/legislatif yaitu perumusan/ penyusunan hukum pidana; Kebijakan aplikatif/yudikatif yaitu penerapan hukum pidana; dan Kebijakan administrasi/eksekutif yaitu tahap pelaksana hukum pidana (Barda Nawawi Arief, 2001). Kebijakan formulasi/legislatif merupakan salah satu dari tiga rangkaian proses kebijakan hukum pidana yang memiliki peranan penting dalam penegakan hukum. Kebijakan formulasi menyediakan pedoman bagi aparat penegak hukum di tahapan aplikasi dan eksekusi pidana. Bab ketentuan pidana dalam UU Minerba merupakan kebijakan formulasi yang merumuskan ketentuan pidana materiil.

Di dalam ketentuan pidana UU Minerba tidak terdapat kualifikasi delik berupa kejahatan dan pelanggaran. Selain itu, di dalam UU Minerba terdapat delik yang dirumuskan dengan sengaja atau yang dikenal dengan delik kesengajaan atau dolus. Dalam hal ini delik yang menghendaki bentuk kesalahan berupa kesengajaan dalam rumusan delik (Eddy O.S. Hiariej, 2016), misalnya terdapat dalam Pasal 159 UU Minerba.

Delik komisi (Commissionis) adalah melakukan perbuatan yang dilarang dalam Undang-Undang (Eddy O.S. Hiariej, 2016) dalam hal ini terdapat dalam Pasal 160 dan Pasal 161A UU Minerba. Berikutnya delik omisi (Omissionis) adalah tidak melakukan perbuatan sebagaimana telah diwajibkan oleh Undang-Undang (Eddy O.S. Hiariej, 2016) seperti yang ada dalam Pasal 161 B UU Minerba.

Terkait dengan penegakan hukum terhadap delik di bidang pertambangan mineral dan batubara, dapat dikemukakan lembaga yang berwenang melakukan penyidikan adalah Polisi Negara Republik Indonesia (POLRI) atau Pejabat Pegawai Negeri Sipil yang lingkungan tugas dan tanggung jawabnya di bidang pertambangan diberi wewenang khusus sebagai penyidik yang dikenal sebagai Pegawai Negeri Sipil Energi Sumber Daya Mineral (PPNS ESDM) sedangkan kewenangan lembaga yang berwenang melakukan penuntutan dan menjalankan putusan pengadilan terhadap pelaku adalah kejaksaan.

Berdasarkan Undang-Undang Nomor 18 Tahun 2004 Tentang Kejaksaan (UU Kejaksaan) dijelaskan bahwa kejaksaan merupakan salah satu badan yang fungsinya berkaitan dengan kekuasaan kehakiman sebagaimana ditetapkan oleh UUD NRI 1945 yang bebas dari pengaruh dan pihak kekuasaan manapun. Dalam menjalankan tugas dan wewenangnya, kejaksaan terbagi menjadi 3 (tiga) bidang yaitu bidang perdata dan tata usaha negara, bidang ketertiban dan ketentraman umum, dan bidang pidana. Dalam bidang Pidana, Kewenangan kejaksaan sudah ditentukan dalam Pasal 30 UU Kejaksaan yakni Pertama, melakukan penuntutan, Atang Ranoemihardja yang menyatakan bahwa penuntutan merupakan penyerahan berkas perkara kepada pengadilan oleh Penuntut Umum agar berkas perkara tersebut dapat diajukan ke Pengadilan (Djoko Prakoso, 1984). Dalam melakukan penuntutan, jaksa juga mempunyai wewenang untuk melakukan prapenuntutan. Berdasarkan penjelasan Pasal 30 ayat (1) UU Kejaksaan, Prapenuntutan adalah tindakan jaksa untuk memantau perkembangan penyidikan setelah menerima pemberitahuan dimulainya penyidikan dari penyidik, mempelajari atau meneliti kelengkapan berkas perkara hasil penyidikan yang diterima dari penyidik serta 
memberikan petunjuk guna dilengkapi oleh penyidik untuk dapat menentukan apakah berkas perkara tersebut dapat dilimpahkan atau tidak ke tahap penuntutan.

Kedua, melaksanakan penetapan hakim dan putusan pengadilan yang telah memperoleh kekuatan hukum tetap, Melaksanakan penetapan hakim dan putusan pengadilan sebagaimana ditetapkan dalam UU Kejaksaan dikenal dengan istilah eksekusi. Berdasarkan Surat Edaran Kejaksaan Agung Republik Indonesia Nomor B-3715/E/EJP/12/2012 Tentang Petunjuk terhadap perkara tindak pidana umum yang tetap (inkracht van gewijsde) tetapi belum dieksekusi, memberikan pengertian bahwa Eksekusi adalah salah satu tupoksi utama Kejaksaan RI yang diamanatkan dalam UU Kejaksaan. Oleh karena itu mengabaikan pelaksanaan eksekusi terhadap perkara yang telah berkekuatan hukum tetap adalah suatu bentuk kelalaian yang serius dan terancam sanksi kode etik maupun peraturan disiplin Pegawai Negeri Sipil (PP Nomor 53 Tahun 2010).

Ketiga, melakukan pengawasan terhadap pelaksanaan putusan pidana bersyarat, putusan pidana pengawasan dan keputusan lepas bersyarat. Keempat, melakukan penyidikan terhadap tindak pidana tertentu berdasarkan undang-undang. Dalam kaitannya dengan kewenangan melakukan penyidikan terhadap tindak pidana tertentu berdasarkan undang-undang. Dengan merujuk Pasal 149 UU Minerba, penyidik yang berwenang untuk melakukan penyidikan tindak pidana lingkungan hidup adalah POLRI dan PPNS-ESDM, atas dasar UU Minerba tersebut kejaksaan tidak berwenang untuk melakukan penyidikan dalam kasus tindak pidana lingkungan hidup. Jika merujuk kepada penjelasan Pasal 30 huruf D UU Kejaksaan dijelaskan bahwa kejaksaan dapat mempunyai kewenangan untuk melakukan penyidikan sebagaimana diatur dalam UndangUndang Republik Indonesia Nomor 26 Tahun 2000 tentang Pengadilan Hak Asasi Manusia dan Undang-Undang Republik Indonesia Nomor 31 Tahun 1999 sebagaimana telah diubah dengan Undang-Undang Republik Indonesia Nomor 20 Tahun 2001 tentang Pemberantasan Tindak Pidana Korupsi.

Kelima, melengkapi berkas tertentu dan untuk itu dapat melakukan pemeriksaan tambahan sebelum dilimpahkan ke pengadilan yang dalam pelaksanaanya dikoordinasikan dengan penyidik. Untuk melakukan pemeriksaan tambahan sebagaimana telah dijelaskan diatas, maka jaksa harus memperhatikan hal-hal sebagai berikut: tidak dilakukan terhadap tersangka; hanya terhadap perkara-perkara yang sulit pembuktiannya, dan/atau dapat meresahkan masyarakat, dan/atau yang dapat membahayakan keselamatan Negara; harus dapat di selesai dalam waktu 14 hari setelah dilaksanakan ketentuan Pasal 110 dan 138 ayat (2) Undang-Undang Nomor 8 Tahun 1981 tentang Hukum Acara Pidana; dan Prinsip koordinasi dan kerjasama dengan penyidik. Berdasarkan kewenangan yang telah dijelaskan, jaksa memiliki peranan penting dalam penegakan hukum di Indonesia karena didasarkan atas supremasi hukum, perlindungan kepentingan hukum atau masyarakat, dan penegakan Hak Asasi Manusia dalam setiap penuntutan yang dilakukan terhadap setiap tindak pidana yang ditanganinya, salah satunya adalah tindak pidana Minerba.

\section{KESIMPULAN}

Kegiatan pengabdian kepada masyarakat kali ini berhasil memberikan pemahaman yang mendalam tentang kebijakan hukum pidana di bidang pertambangan mineral dan batubara. Pengabdian kepada masyarakat ini juga memberikan pemahaman perihal pentingnya peran jaksa dalam melakukan penuntutan terhadap pelaku tindak pidana pertambangan mineral dan batubara.

\section{Ucapan Terima Kasih (Acknowledgement)}

Ucapan terima kasih kepada Lembaga Penelitian dan Pengabdian kepada Masyarakat (LPPM) Universitas Tarumanagara dan berbagai pihak yang telah membantu. 
Seminar Nasional Hasil Penelitian dan Pengabdian Kepada Masyarakat 2021

Pengembangan Ekonomi Bangsa Melalui Inovasi Digital Hasil Penelitian dan

Pengabdian Kepada Masyarakat

Jakarta, 21 Oktober 2021

\section{REFERENSI}

Buku

Arief, Barda Nawawi. Bunga Rampai Kebijakan Hukum Pidana: Perkembangan Penyusunan Konsep KUHP Baru, (Jakarta: Kencana, 2011)., Kapita Selekta Hukum Pidana, (Bandung: PT Citra Aditya Bakti, 2003)., (Sari Kuliah) Perbandingan Hukum Pidana, ( Jakarta: PT Raja Grafindo Persada, 2002)., Masalah Penegakan Hukum dan Kebijakan Penanggulangan Kejahatan, (Citra Aditya Bakti, Bandung, 2001).

Haryadi, Dwi. Pengantar Hukum Pertambangan Mineral dan Batubara (Bangka Belitung: UBB Press, 2018).

Hiariej. Eddy O.S., Prinsip-Prinsip Hukum Pidana (Yogyakarta: Cahaya Atma Pustaka,2016).

Keraf, A. Sonny. Etika Lingkungan Hidup. (Jakarta: Kompas, 2010).

MD, Moh Mahfud. Politik Hukum di Indonesia. (Jakarta: LP3ES, 1998).

Prodjodikoro, Wirjono. Asas-Asas Hukum Pidana di Indonesia. (Bandung: Refika Aditama. 2003)

Prakoso, Djoko, Tugas dan Peran Jaksa dalam Pembangunan, (Jakarta: Ghalia Indonesia, 1984)

Redi, Ahmad. Hukum Sumber Daya Alam Dalam Sektor Kehutanan, (Jakarta: Sinar Grafika, 2014).

Sembiring. Simon F., Jalan Baru Tambang: Mengalirkan Berkah bagi Anak Bangsa. (Jakarta: Gramedia, 2009).

Warlina, Lina. Manajemen Pembangunan dan Lingkungan (Tangerang Selatan: Universitas Terbuka,2014)

Lamintang. Dasar-Dasar Hukum Pidana Indonesia. (Bandung: PT. Citra Aditya Bakti,2013)

\section{Jurnal/Makalah}

Jilaan Ronaa Aanisah, et.al., "Penyusunan Neraca Kekayaan Negara: Konsep dan Problematika", Simposium Nasional Keuangan Negara.

Lepa, Victory Prawira Yan, Pidana Pengawasan Dalam Sistem Pemidanaan Indonesia, Lex Administratum Volume II No.3 Tahun 2014

\section{Peraturan Perundang-undangan dan Yurisprudensi}

Indonesia. Undang-Undang Dasar Republik Indonesia Tahun 1945, Cetakan Keenam, (Jakarta: Kepaniteraan dan Sekretariat Jenderal Mahkamah Konstitusi RI, 2016). . Undang-Undang Nomor 4 Tahun 2009 tentang Pertambangan Mineral dan Batubara. . Undang-Undang Nomor 3 Tahun 2020 tentang perubahan atas Undang-Undang Nomor 4 Tahun 2009 tentang Pertambangan Mineral dan Batubara.

. Undang-Undang Republik Indonesia Nomor 32 Tahun 2009 Tentang Perlindungan dan Pengelolaan Lingkungan Hidup sebagaimana telah diubah dengan Undang-Undang Nomor 11 Tahun 2020 tentang Cipta Kerja. , Putusan Mahkamah Konstitusi Perkara Nomor 002/PUU-I/2003.

\section{Website}

Badan Pusat Statistik "Produksi tambang mineral 2017-2019 https://www.bps.go.id/indicator/10/508/1/produksi-barang-tambang-mineral.html,

Rahmadi, May. "Nasib Lubang Tambang di bawah revisi UU Minerba" https://www.ekuatorial.com/2020/06/nasib-lubang-tambang-di-bawah-revisi-uu-minerbal,

Pakpahan, Rudy Hendra. "Efektifitas Pidana Denda" https://sumut.kemenkumham.go.id/berita-kanwil/berita-utama/efektifitas-pidana-denda. 


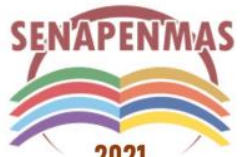

2021
Seminar Nasional Hasil Penelitian dan Pengabdian Kepada Masyarakat 2021

Pengembangan Ekonomi Bangsa Melalui Inovasi Digital Hasil Penelitian dan Pengabdian Kepada Masyarakat Jakarta, 21 Oktober 2021

Setiawan, Verda Nano. "Aturan Baru UU Minerba Berbuah Kriminalisasi Penolak Tambang" https://katadata.co.id/safrezifitra/berita/60d087615c241/aturan-baru-uu-minerbaberbuah-kriminalisasi-penolak-tambang

Utomo, Anandito, Arti Pidana Bersyarat dan Pembebasan Bersyarat, "https://www.hukumonline.com/klinik/detail/ulasan/lt517dec08d1200/arti-pidanabersyarat-dan-pembebasan-bersyarat" 
Seminar Nasional Hasil Penelitian dan Pengabdian Kepada Masyarakat 2021

Pengembangan Ekonomi Bangsa Melalui Inovasi Digital Hasil Penelitian dan

Pengabdian Kepada Masyarakat

Jakarta, 21 Oktober 2021

(halaman kosong) 